\title{
Mitigating social and economic sources of trauma: the need for Universal Basic Income during the Coronavirus Pandemic
}

\author{
Dr Matthew Johnson, ${ }^{1}$ Elliott Johnson, ${ }^{2}$ Dr Laura Webber, ${ }^{3}$ Prof Daniel Nettle ${ }^{4}$
}

(C) 2020, American Psychological Association. This paper is not the copy of record and may not exactly replicate the final, authoritative version of the article. Please do not copy or cite without authors' permission. The final article will be available, upon publication, via its DOI: $10.1037 / \operatorname{tra} 0000739$

Abstract: The COVID-19 Pandemic is projected to cause an economic shock larger than the Global Financial Crisis of 2007/2008 and a recession as great as anything seen since the Great Depression in 1930s. The social and economic consequences of lockdowns and social distancing measures, such as unemployment, broken relationships and homelessness create potential for inter-generational trauma extending decades into the future. In this article, we argue that, in the absence of a vaccine, governments need to introduce Universal Basic Income as a means of mitigating this trauma.

Keywords: Economic shock; unpredictability; trauma; Universal Basic Income

Clinical Impact Statement: Government action to address the COVID-19 Pandemic has mitigated mortality and reduced the possibility of intensive care services being overwhelmed. However, it has also created social and economic sources of trauma, heightening potential for unemployment, relationship breakdown and homelessness. Given that psychological and psychiatric services are already stretched in the wake of the Global Financial Crisis and era of austerity, we need to consider means of mitigating this secondary source trauma. It is important that practitioners consider support for Universal Basic Income as a means of enabling people to satisfy their basic needs and plan their lives securely.

The American Psychological Association (2020) states that

Trauma is an emotional response to a terrible event like an accident, rape or natural disaster. Immediately after the event, shock and denial are typical. Longer term reactions include unpredictable emotions, flashbacks, strained relationships and even physical symptoms like headaches or nausea. While these feelings are normal, some people have difficulty moving on with their lives.

Trauma stems from events that pose (existential) threats to the self. COVID-19 casts into sharp relief the threat from communicable disease. Individuals live daily with the possibility of their and their loved ones' lives being curtailed by the virus. However, it is not just the illness itself that is traumatic. The economic shock imposed by response to the pandemic is projected to

\footnotetext{
${ }^{1}$ Matthew Thomas Johnson, PhD, Senior Lecturer in Politics, Lancaster University. ORCID ID: 0000-00029987-7050. m.johnson@lancs.ac.uk

${ }^{2}$ Elliott Aidan Johnson, MA, Disability Research Consultant. ORCID ID: 0000-0002-0937-6894. ejohnsonresearch@gmail.com

${ }^{3}$ Chief Operating Officer and Co-founder, HealthLumen; Honorary Assistant Professor, London School of Hygiene and Tropical Medicine. ORCID ID: 0000-0002-8976-1919. Laura.Webber@ healthlumen.com

${ }^{4}$ Daniel Nettle, Professor of Behavioural Science, Newcastle University. ORCID ID: 0000-0001-9089-2599. daniel.nettle@newcastle.ac.uk
} 
exceed that caused by the 2007/2008 Global Financial Crisis and threatens a recession as great as anything seen since the 1930s (Gopinath 2020). The young, the fit and the healthy, who may, at one point, have been dismissive toward the physical consequences of infection (Foroohar 2020), now see their existential interests threatened economically too.

Governments have taken a number of measures to impose isolation and quarantining as a means of protecting the vulnerable and national health services. This has caused consumer behavior to change, businesses to fold, employees to be made redundant and lifelines removed. Without employment or adequate social security, individuals face both a 'social' death in isolation from their communities and the removal of means of satisfying basic needs. This threat of destitution has emerged suddenly and with little warning, depriving individuals of means of planning and preparation. It is every bit as unpredictable and overwhelming as phenomena associated with natural disaster (see APA 2013). While there have been other economic shocks in recent times, none have been so deeply entwined with the possibility of imminent potential social or actual demise for so many.

The traumatic consequences of economic shock are myriad. Divorce and separation (Dremen 1991), domestic violence (Duxbury 2006), homelessness (Goodman, Saxe and Harvey 1991), are all heightened by destitution and all associated with trauma. They are also the sources of further trauma in children of parents and families affected, creating inter- and trans-generational sources of trauma (Khouri, et al. 2010). COVID-19 has the potential for psychological consequences spanning decades into the future.

As with so many health issues, prevention or mitigation of trauma is better than cure. With treatment uneven and uncertain and vaccines still in the early phases of development, dealing with COVID-19 as a virus directly is fraught. However, governments do have at their disposal means of mitigating some of the trauma associated with the social and economic consequences. In Spain, the Government has announced that it will introduce Universal Basic Income (UBI) - what former US Presidential Primary Candidate Andrew Yang referred to as The Freedom Dividend (Yang2020 2020) - as a direct response to COVID-19 (Ng 2020). This is a cash transfer to all adult citizens regardless of means or needs. Historically, it has been justified by those on the left and right variously as a means of promoting citizens' rights (Pettit 2008), increasing efficiency in welfare systems (Gordon 2014) and promoting growth (Sheahan 2003). While the BMJ has called for a trial on health grounds (Painter 2016), and while trials of UBI have indicated self-reported reductions in stress (Kangas, et al. 2019, 30), the health case remains neglected by policy makers (see Johnson, Johnson and Webber 2020) and the focus on its role in mitigating trauma may be compelling.

We know that trauma has long-term psychological and physical consequences (McFarlane 2010). UBI is a means of mitigating trauma from events associated with economic shock, just as it reduces stress from unpredictability. By reducing poverty and enabling people to overcome periods of unemployment, UBI reduces 'health inequalities and the structural conditions that put people "at risk of risks", such as "discrimination, poverty, residential segregation, inadequate schools, unemployment' (Thoits, 2010, S47). Existing evidence suggests that, by acting as a safety net of predictable, certain income, UBI reduces psychological stress (see Kangas, et al. 2019, 25; Johnson and Johnson 2019) as well as having 'modest to strong positive effects on a range of health outcomes, including low birthweight, adult and child mental health, service use, and diet' (Gibson, Heart and Craig $(2018,11)$.

Having predictable, adequate income serves as a response to Webber and colleagues' (2018) call for 'upstream interventions' to promote health. It means that individuals can perform roles as partners, parents, family members and workers much more effectively than under uncertain conditions. That serves to reduce the strain on relationships, meaning that interpersonal sources of trauma are reduced. In already traumatic circumstances, it gives individuals the 'power to say no' (Widerquist 2013, 27), perhaps escaping being trapped in 
lockdown in an abusive relationship or rejecting unreasonable demands from an employer seeking to take advantage of the current situation.

Even if we cannot yet eliminate the trauma of death by infection, we can limit those traumas related to it. Not taking such steps during a pandemic is not only unpragmatic, it could also be terribly costly. It must be remembered that the Great Depression of the 1930s preceded the Second World War, the Holocaust, the Cold War and decades of trauma. As demand is already overwhelming for psychological and psychiatric services in the wake of the Global Financial Crisis and era of austerity, we may be unable to deal with the consequences of avoidable trauma if we do not act now.

\section{References}

American Psychological Association (2020). Trauma. American Psychological Association, $<$ https://www.apa.org/topics/trauma/> [Accessed 5 April 2020].

American Psychological Association (2013). Recovering emotionally from disaster. American Psychological Association, < https://www.apa.org/helpcenter/recovering-disasters> [Accessed 5 April 2020].

Dreman, S. (1991). Coping with the trauma of divorce. Journal of Traumatic Stress, 4, 113121.

Duxbury, S. (2006). Recognizing domestic violence in clinical practice using the diagnoses of posttraumatic stress disorder, depression and low self-esteem. British Journal of General Practice, 56(525), 294-300.

Foroohar, R. (2020). Covid-19 and the generational divide. Financial Times, 16 March. Available at: <https://www.ft.com/content/6a880416-66fa-11ea-800d-da70cff6e4d3> [Accessed 15 April 2020].

Gopinath, G. (2020). The Great Lockdown: Worst Economic Downturn Since the Great Depression. IMFBlog, 14 April <https://blogs.imf.org/2020/04/14/the-great-lockdownworst-economic-downturn-since-the-great-depression/> [Accessed 15 April 2020].

Johnson, M.T. and Johnson, E.A. (2019). Stress, Domination and Basic Income: Considering a citizens' entitlement response to a public health crisis. Social Theory \& Health, 17, 253-271.

Kangas, O., Jauhiainen, S., Simanainen, M., Ylikännö, M. (2019). The basic income experiment 2017-2018 in Finland: Preliminary results. Helsinki: The Ministry of Social Affairs.

Khoury, L., Tang, Y. L., Bradley, B., Cubells, J. F., \& Ressler, K. J. (2010). Substance use, childhood traumatic experience, and Posttraumatic Stress Disorder in an urban civilian population. Depression and anxiety, 27(12), 1077-1086.

Lake, J. I., \& Labar, K. S. (2011). Unpredictability and uncertainty in anxiety: a new direction for emotional timing research. Frontiers in integrative neuroscience, 5, 55.

McFarlane A. C. (2010). The long-term costs of traumatic stress: intertwined physical and psychological consequences. World psychiatry: official journal of the World Psychiatric Association (WPA), 9, 3-10.

$\mathrm{Ng}, \mathrm{K}$. (2020). Coronavirus: Spain to become first country in Europe to roll out universal basic income. The Independent, 6 May, <https://www.independent.co.uk/news/world/europe/coronavirus-spain-universalbasic-income-europe-a9449336.html> [Accessed 27 January 2020].

Thoits, P. A. (2010). Stress and Health: Major Findings and Policy Implications. Journal of Health and Social Behavior, 51(S), S41-S53.

Webber, L., Chalkidou, K., Morrow, et al. (2018). What are the best societal investments for improving people's health?. BMJ, 362, k3377. 
Widerquist, K. (2013) Independence, propertylessness, and basic income. New York: Palgrave Macmillan.

Yang2020 (2020). The Freedom Dividend. Yang2020, <https://www.yang2020.com/what-isfreedom-dividend-faq/> [Accessed 27 January 2020]. 